Jurnal PG-PAUD Trunojoyo : Jurnal Pendidikan dan Pembelajaran Anak Usia Dini, Volume 8, Nomor 1, April 2021 hal 15 - 25, ISSN : 2528-3553 (online), ISSN: 2407-4454 (print)

\title{
Implementasi Program Kidspreneurship pada TK Khalifah di Kalimantan Selatan
}

\author{
Nor Izzatil Hasanah ${ }^{1}$ \\ ${ }^{1}$ Programstudi PIAUD, UIN Antasari Banjarmasin \\ izhanorhasanah@gmail.com
}

Received (Januari), Accepted (Maret), Published (April)

\begin{abstract}
Implementation of Kidspreneurship Program for Khalifah Kindergarten in South Kalimantan. This study is aimed to determine the concept of kidspreneurship which is applied to Khalifah Kindergarten in South Kalimantan, program implementation and also supporting and inhibiting factors in implementing kidspreneurship program. This research used a qualitative descriptive approach in form of case study. To collect the data, researcher used observation, interview and documentation techniques. The results showed that the kidsprenuership program at Khalifah Kindergarten was divided into 2 programs that focused on soft skills and hard skills. Soft skills developed for children were entrepreneurial values. Meanwhile, hard skills were more about introducing business to children in form of financial literacy, making products to marketing products. These soft skills and hard skills were implemented through knowing, feeling and acting. Knowing is carried out to introduce children to the concept, it is taught by talking and song methods. Feeling is done by reading a story. While acting is done through role playing activities, methods of giving assignments and habituation. To maximize the kidpreneurship activities, Khalifah Kindergarten has other additional activities such as cooking days, field trips to the place for processing and sales of certain products, market days and Ramadan market. In implementing this program, it is inseparable from supporting and inhibiting factors, namely cooperation between teachers and parents, seminars and workshops on kidsprenuership, learning media, geographical location, class and school sizes, and peers.
\end{abstract}

Keywords: Implementation, Kidspreneurship, Khalifah, Kindergarten

\begin{abstract}
Abstrak: Implementasi Program Kidspreneurship pada Paud Khalifah di Kalimantan Selatan. Tujuan dari penelitian ini adalah untuk mengetahui konsep kidspreneurship yang diterapkan pada TK Khalifah di Kalimantan Selatan, implementasi program serta faktor yang mendukung dan menghambat implementasi program kidspreneurship tersebut. Penelitian ini menggunakan pendekatan kualitatif deskriptif jenis studi kasus. Untuk mengumpulkan data, peneiti menggunakan teknik observasi, wawancara dan dokumentasi. Hasil penelitian ini menunjukkan bahwa program kidsprenuership di $\mathrm{Tk}$ Khalifah terbagi menjadi 2 program yang menitikberatkan pada softtskill dan hard skill. Soft skill yang dikembangkan kepada anak merupakan enterpreuership value. Sedangkan hard skill lebih kepada pengenalan bisnis kepada anak dalam bentuk literasi keuangan, membuat produk hingga memasarkan produk. Soft skill dan hard skill ini diimplementasikan melalui knowing, feeling dan acting. Knowing dilaksanakan untuk mengenalkan anak terhadap konsep, ini diajarkan dengan metode bercakapcakap dan lagu. Feeling dilakukan dengan cara membacakan sebuah cerita. Sedangkan acting dilakukan melalui kegiatan bermain peran, metode pemberian tugas dan pembiasaan. Untuk memaksimalkan kegiatan kidspreneurship, TK Khalifah memiliki kegiatan tambahan lain seperti cooking day, berkaryawisata ke tempat pengolahan dan penjualan produk tertentu, market day dan ramadhan market. Faktor pendukung dan penghambat program ini adalah kerjasama guru dan orang tua, seminar dan workshop tentang kidsprenuership, media pembelajaran, letak geografis, ukuran kelas dan sekolah, dan teman sebaya.
\end{abstract}

Kata kunci: Implementasi, Kidspreneurship, Khalifah, TK 
Jurnal PG-PAUD Trunojoyo : Jurnal Pendidikan dan Pembelajaran Anak Usia Dini, Volume 8, Nomor 1, April 2021 hal 15 - 25, ISSN : 2528-3553 (online), ISSN: 2407-4454 (print)

\section{PENDAHULUAN}

Lingkungan sekolah terus berubah sebagai respon perubahan zaman. Ada banyak aspek yang harus dimuat ke dalam kurikulum, bahkan untuk pendidikan anak usia dini. Masalah Keberlanjutan pendidikan, ketimpangan sosial, keragaman, gender dan demokrasi dapat disebut sebagai contoh dari adaptasi ini. Dewasa ini, pendidikan entrepreunership menjadi topik hangat dalam dunia pendidikan sebagai respon ketidaksesuaian (mismatch) output pendidikan dengan kebutuhan dunia kerja. Dengan adanya hubungan kontekstual dengan pendidikan itulah yang menempatkan pembelajaran kewirausahaan sebagai pusat perhatian.

Berdasarkan pengaruhnya terhadap ekspansi ekonomi dan penciptaan lapangan kerja, pemerintah tampaknya telah menemukan solusi utama untuk ekonomi dan tantangan sosial yang dihadapi negara melalui pendidikan entrepreunership. Perkembangan ini terjadi di seluruh dunia dan di banyak negara seperti Inggris, Cina, AS, dan Finlandia berupaya mempromosikan kewirausahaan dengan mempengaruhi sistem sekolah melalui kebijakan dan kurikulum (Seikkula-Leino, J., 2011).salah satu kebijakan yang sedang dilaksanakan oleh pemerintah finlandia adalah program powerprenuer. Program ini meyakini bahwa keterampilan enterprenueship merupakan hal yang sangat dibutuhkan anak usia dini untuk menajuan di masa mendatang.

Ketika entrepreunership diperkenalkan ke konteks anak usia dini, ternyata ditemukan tantangan baru yang harus ditanggapi oleh para akademisi. Retorika sekolah tentang entrepreunership lebih identik dengan kepemilikan bisnis. Dengan konotasi ini, timbul keengganan guru untuk menanamkan pendidikan entrepreunership bagi anak didiknya.

Penelitian tentang entrepreunership memang masih menjadi Fenomena baru dalam dunia pendidikan. Karenanya konsep ini dan pembelajarannya di lingkungan sekolah tidak sepenuhnya dieksplorasi atau didefinisikan secara eksplisit dalam penelitian. Definisi yang berlaku dan berkembang di sekolah sangat dipengaruhi oleh otoritas publik. Dalam konteks pendidikan anak usia dini, tidak jelas apa jenis entrepreneur yang harus dituju, dan kompetensi wirausaha seperti apa yang perlu untuk dikembangkan. Padahal, masa usia dini dan remaja dianggap sebagai kelompok usia yang paling tepat untuk memperoleh sikap positif melalui pendidikan entrepreunership (Peterman, N. E., \& Kennedy, J., 2003). Korhonen, M., Komulainen, K., \& Räty, H., (2012) emudian membagi istilah kewirausahaan menjadi dua wacana: satu wacana kewirausahaan yang menyangkut bisnis dan perusahaan, dan wacana penanaman enterprenuership values.

Kewirausahaan yang menyangkut bisnis adalah kemampuan seseorang dalam memproduksi dan memasarkan produk, sedangkan enterprenuership values ditujukan untuk pengembangan pribadi dan meningkatkan keterampilan kewirausahaan yaitu kemampuan anak-anak untuk memulai, mencari peluang, bertanggung jawab, partisipatif, percaya diri dan kreatif. Ketegangan di antara dua perspektif kewirausahaan ini dapat dilacak dalam penelitian sebelumnya, yang menunjukkan bahwa guru menunjukkan sikap ambigu dalam mengajar kewirausahaan dengan fokus bisnis atau pendekatan kewirausahaan internal dalam menanamkan aspek-aspek positifnya

Dengan latar belakang pemikiran di atas dan pre-observasi pada TK Khalifah yang merupakan TK dengan sistim waralaba dan satu-satunya TK yang menerapkan pendidikan entrepreunership untuk AUD berbasis tauhid di Kalimantan Selatan, maka riset ini dilakukan dalam rangka mengidentifikasi implementasi program kidspreneurship yang diterapkan pada TK Khalifah, dengan menitikberatkan pada bagaimana konsep kidspreneurship yang diterapkan oleh guru, implementasi program kidspreneurship dan faktor pendukung dan penghambat dalam 
Jurnal PG-PAUD Trunojoyo : Jurnal Pendidikan dan Pembelajaran Anak Usia Dini, Volume 8, Nomor 1, April 2021 hal 15 - 25, ISSN : 2528-3553 (online), ISSN: 2407-4454 (print)

implementasi program kidspreneurship di TK tersebut.

Sebelum melakukan penelitian, peneliti menelaah karya ilmiah yang berkaitan dengan penelitian yang akan dilaksanakan, diantaranya: Penelitian Tindak Kelas yang dilakukan oleh Syifauzakia (2016) tentang Penanaman Nilai-Nilai Kewirausahaan Pada Anak kelompok B2 RA Miftahul Falah Melalui Metode Proyek. Setelah PTK selesai dilaksanakan dalam 4 siklus, muncul 11 nilai-nilai karakter wirausahawan pada anak yaitu mandiri, kreatif, mengambil resiko, berorientasi pada tindakan, keberanian untuk memimpin, bekerja keras, disiplin, bertanggung jawab, bekerja sama, rasa penasaran dan kemampuan berkomunikasi. Adapun faktor munculnya 11 karakter tersebut adalah strategi guru dalam pembelajaran, media yang digunakan, kalaborasi antara guru dan peneliti, kegiatan belajar mengajar yang menarik, unjuk kerja dan pengaruh teman sebaya.

Distingsi penelitian ini dengan penelitian terdahulu adalah bahwa penelitian ini bertujuan untuk mendeskripsikan implementasi pendidikan entrepreneurship yang dilaksanakan oleh satu-satunya TK system jaringan (franchise) yang menjadikan pendidikan kewirausahaan sebagai ciri khasnya. Dari penelitian ini dapat diungkap bagaimana kombinasi antara penanaman system nilai dalam kewirausahaan (softskill) dan kemampuan mengelola bisnis termasuk literasi keuangan bagi AUD (hardskill).

\section{METODE}

Penelitian ini menggunakan pendekatan peneltian kualitatif deskriptif jenis studi kasus. Penelitian ini mengambil lokasi di TK Khalifah Banjarmasin yang berada di Jalan perdagangan No. 818 Rt. 30 Kelurahan Alalak, Kecamatan Banjarmasin Utara, Kota Banjarmasin

Data dalam penelitian ini bersumber dari person, narasumber yang mengetahui tentang implementasi pendidikan entrepreneurship pada AUD di TK Khalifah, mulai dari kepala sekolah, komite sekolah, guru, TU hingga anak didik. Place adalah gambaran lokasi penelitian. Dari gambaran lokasi ini dapat diketahui karakteristik khusus yang merupakan kearifan lokal dalam implementasi pendidikan entrepreneurship di TK Khalifah Banjarmasin. Paper adalah dokumen yang berkaitan dengan masalah penelitian. Ada tiga metode yang dipakai dalam mengumpulkan data penelitian ini, yaitu observasi. wawancara, dan dokumentasi. Untuk menganalisis data peneliti menggunakan adalah reduksi, display dan penyimpulan data.

\section{HASIL DAN PEMBAHASAN}

\section{Konsep Kidspreneurship di TK Khalifah Banjarmasin}

Hasil penelitian menunjukkan, terdapat 2 konsep kidprenuership yang diterapkan di TK khalifah Banjarmasin, yakni konsep penanamkan nilai-nilai enterprenurship (softskill) dan pengenalan tentang literasi keuangan, pembuatan produk dan pemasarannya atau bisnis (hardskill). Hal tersebut sejalan dengan pendapat Korhonen yang membagi istilah kewirausahaan menjadi dua wacana: satu wacana kewirausahaan yang menyangkut bisnis dan perusahaan, dan wacana kewirausahaan lainnya yang ditujukan untuk pengembangan pribadi dan meningkatkan keterampilan kewirausahaan yaitu kemampuan anakanak untuk memulai, mencari peluang, bertanggung jawab, partisipatif, percaya diri dan kreatif (Korhonen, M., Komulainen, K., \& Räty, H., 2012).

Pada konsep atau aspek penanaman nilai-nilai enterprenurship (softskill), nilai-nilai yang dikenalkan di TK Khalifah Banjarmasin adalah kejujuran, sabar, kerja keras, kreatif, mandiri, rasa ingin tahu, komunikatif, tanggung jawab, kerja tim, menerima kegagalan dan saling berbagi, sabar dan santun. Sedangkan pada aspek hard skill, TK 
Jurnal PG-PAUD Trunojoyo : Jurnal Pendidikan dan Pembelajaran Anak Usia Dini, Volume 8, Nomor 1, April 2021 hal 15 - 25, ISSN : 2528-3553 (online), ISSN: 2407-4454 (print)

khalifah mengenalkan konsep literasi keuangan (seperti nilai mata uang, cara membayar dan memberikan kembalian beserta akad saat transkasi jual beli), pembuatan produk (seperti anak diajak membuat bubur, pizza, jagung susu keju, roti bakar dan lain-lain secara bersama-sama di sekolah) dan pemasarannya (melalui kegiatan bermain peran bersama teman hingga memasarkan atau menjual produk olahan sendiri di pasar Ramadhan kepada masyarakat umum, kegiatan ini biasanya didampingi oleh orang tua).

\section{Implementasi}

Program

\section{Kidspreneurship di TK Khalifah} Banjarmasin

Pelaksanaan kegiatan enterpreneurship di TK khalifah sifatnya terpadu atau terintegrasi dengan berbagai kegiatan pengembangan 6 aspek perkembangan anak. Sehingga 6 aspek perkembangan dasar anak tetap menjadi fokus perhatian utama. Hal tersebut juga dikuatkan oleh Mulyani (2010) bahwa pembelajaran di PAUD berbasis tema, sehingga pendidikan kewirausahaan dapat dikaitkan dengan berbagai kegiatan disekolah baik kegiatan ekstrakurikuler maupun intrakurikuler. Dengan demikian guru hanya perlu menggunakan materi ajar untuk mengembangkan kewirausahaan.

Meskipun demikian, tetap diperlukan upaya agar program kidpreneurship tersebut terlaksana secara maksimal maka perlu melalui proses perencanaan, pelaksanaan, dan evaluasi pembelajaran.

a. Perencanaan

Perencanaan pembelajaran merupakan hal mendasar dalam proses pembelajaran. Dengan merancang sebuah kegiatan pembelajaran maka proses pembelajaran akan berjalan secara terarah. Oleh karena itu guru perlu menrencanakan secara matang mengenai kegiatan kidpreneurship yang akan dilaksanakan serta interpreneurship values apa saja yang akan ditanamkan kepada anak.

Dalam mengembangkan kegiatan pembelajaran interprenuership yang terintegrasi dalam kegiatan pembelajaran, kepala sekolah dan dewan guru TK Khalifah merancang program tahunan, dan semsester di setiap tahun ajaran baru serta merancang perencanaan harian pada setiap harinya agar kegiatan selalu menyesuaikan dengan hasil evaluasi di setiap kegiatan yang telah terlaksana. Perencanaan tersebut berlandaskan pada kurikulum yang diberikan oleh TK Khalifah Pusat. sehingga guru-guru yang berada di TK khalifah Banjarmasin mengembangakan kegiatan berdasarkan apa yang sudah tersusun dan kemudian disesuai dengan kondisi masingmasing daerah. Suryosubroto (2002) menjelaskan bahwa jika suatu kegiatan tidak direncanakan dengan baik maka tujuan dari kegiatan tersebut tidak akan tercapai secara maksimall. Selain itu, perencanaan di TK Khalifah juga sudah berangkat dari program tahunan, Semester dan dirincikan secara deteal pada perencanaan Harian. Masitoh, dkk (2009) menjelaskan bahwa penyusunan perencanaan pembelajaran yang baik memang harus memuat Prota, Promes, RPPM dan RPPHn. Dengan demikian, TK Khalifah sudah memiliki perencanaan dan tujuan kegiatan yang jelas dan terarah dalam setiap tahunnya.

Selain itu, agar kegiatan enterprenuership dapat terlaksana secara lebih maksimal, pihak sekolah juga melibatkan para orang tua untuk memberikan masukan serta sebagai bentuk transparansi tentang bentuk kegiatan yang akan dilaksnakan, waktu, pembiayaan, 
Jurnal PG-PAUD Trunojoyo : Jurnal Pendidikan dan Pembelajaran Anak Usia Dini, Volume 8, Nomor 1, April 2021 hal 15 - 25, ISSN : 2528-3553 (online), ISSN: 2407-4454 (print)

pengelolaan serta tindak lanjut yang akan dilakukan setelah kegitan enterprenuership terlaksna. Menurut Syifauzakia (2016) upya Kerjasama antara pihak sekolah, guru dan orang tua memang harus terjalin dengan baik agar programprogram kegiatan yang di rancang oleh lembaga pendidkan bisa berjalan dengan efektif. sehingga sedari awal pihak orang tua sudah mengetahui dan memahami apa saja kegiatan yang akan dilakukan anak serta bagaimana keterlibatan orang tua pada kegiatan-kegiatan enterprenuership ketika mereka menyekolahkan anak mereka di TK Khalifah Banjarmasin.

Dalam program semester di TK Khalifah sudah tercantum tema apa saja yang akan dibahas selama 6 bulan ke depan, tema pada program semester ini menjadi acuan guru dalam merancang rencana kegiatan mingguan dan harian anak. Penentuan tema sangatlah penting pada kegiatan di TK, karena pembelajaran di TK tidak menggunakan mata pelajaran. Meskipun tema yang di rancang di TK Khalifah terdengar berbeda dengan tema-tema di $\mathrm{Tk}$ pada umumnya, namun pada penerapannya tema-tema terebut memiliki kesamaan, perbedaanya adalah setiap tema sudah dikaitkan dengan kewirausahaan.

Penyusunan RPPH yang mengacu pada tema membantu guru dalam mengaitkan pembelajaran dengan kegiatan entrepreneurship. Seperti ketika tema "Pasar Sebagai Tempat Jual Beli" maka dari tema tersebut guru dapat merencanakan kegiatan yang dapat menumbuhkan jiwa wirausaha pada diri anak, seperti kegiatan bermain peran, hari jual beli, kelas memasak dan dan kunjungan kelas ke tempat-tempat tertentu, serta nilai-nilai kewirausahaan apa yang akan ditanamkan kepada anak. Tapi, tidak dapat dikesemapingkan bahwa tidak semua tema dapat dikaitkan dengan kegiatan enterpreneurship. Misalnya saja tema alam semesta, untuk tema ini tidak dapat dikaitkan dengan kegiatan enterprenuership untuk AUD. Sehingga pada tema-tema seperti ini guru dapat mengeksplorasi berbagai kegiatan bermain yang lain untuk mengembangkan berbagai aspek perkembangan anak. Sehingga kegiatan di TK tetap terus bervariasi dan menyenangkan bagi anak sebagaimana prinsip pembelajran di TK yakni aktif, kreatif, interaktif, efektif dan menyenangkan bagi anak (Permendinas No 58, 2009).

b. Pelaksanaan

Pembelajaran adalah proses interkasi antara guru dengan anak didik melalui kegiatan bermain dengan menggunakan berbagai sumber belajar yang aman dan sesuai dengan perkembangan anak. Menurut Ningrum, untuk melaksanaan kegiatan pembelajaran pada anak usia dini haruslah mengacu pada prinsip-prinsip berikut: memperhatikan kebutuhan anak, belajar melaui bermain, kegiatan belajar mengembangkan mengembangkan berbagai aspek perkembangan anak secara terpadu, menggunakan pendekatan individu, kelompok serta klasikal, lingkungan yang nyaman, model pembelajaran yang bervariasi, mengembangkan life skill dan hidup beragama, menggunakan berbagai sumber dan media belajar, dan beorientasi pada prinsip perkembangan anak (2017).

Melihat prinsip-prinsip tersebut, jika kita rincikan satu persatu tentang bagaimana pelaksanaan pembelajaran di TK Khalifah 
Jurnal PG-PAUD Trunojoyo : Jurnal Pendidikan dan Pembelajaran Anak Usia Dini, Volume 8, Nomor 1, April 2021 hal 15 - 25, ISSN : 2528-3553 (online), ISSN: 2407-4454 (print)

Banajarmasin, dimulai dari kesesuaian dengan kebutuhan dan perkembangan anak, maka berdasarkan hasil wawancara dan pengamatan peneliti, pelaksanaan pembelajaran di TK Khalifah Banjarmasin dilaksanakan sesuai dengan kebutuhan anak. Hal tersebut terlihat dari indikatorindikator yang ingin dicapai dalam setiap pertemuan disesuaikan dengan usia dan capaian perkembangan anak. Setiap kegiatan dirancang untuk mengembangkan 6 aspek dasar perkembangan anak secara seimbang. Selain itu, setiap anak mendapatkan perhatian, rasa aman, dan kasih sayang yang sama oleh guru.

Proses pelaksanaan pembelajaran dilakukan dengan cara belajar melalui bermain. Selain itu dalam proses pembelajaran ibu guru menggunakan pendekatan secara klasikal, kelompok dan individu. Ada waktu agar anak-anak melakukan kegiatan dengan cara klasikal, begitu pula dengan kegiatan secara kelompok maupun individu.

TK Khalifah ini terletak di daerah yang agak ramai dan bisa disebut daerah perdagangan sehingga sangat mendukung dalam kegiatan pembelajaran enterpreneurship, khususnya saat anak dan orang tua bekerjasama memasarkan atau menjual produk yang dibuat pada kegitan market day dan ramadan market. Mengenai ruang belajar-mengajar ataupuna area lainnya terlihat kondusif. Baik ketika anak-anak melakukan kegiatan awal di halaman seperti baris-berbaris dan sebagainya, maupun saat kegiatan pembukaan, inti dan penutup kondisinya kondusif.

Terkait dengan model pembelajaran, di TK Khalifah Banjarmasin menggunakan model pembelajaran sentra. Sentra yang disediakan cukup banyak yaitu Sentra Tauhid (diselenggarakan setiap pagi), Sentra Alam, Sentra Balok, Sentra Life Skill (Bermain Peran), dan Sentra Seni. Meskipun demikian, kegiatan-kegiatan yang dilakukan anak di TK Khalifah sangat variatif tidak hanya fokus di sentra saja karena TK Khalifah Banjarmasin berbasis tauhid dan entrepreneurship. Sehingga jika ada kegiatan kewirausahaan, anak-anak pun akan melakukan kegiatan outing class, market ramadan, cooking class dan menonton slide show. Meskipun ini tidak dilakukan setiap hari, karena masing-masing kegiatan ada jadwal tertentu.

Mengenai prinsip pembelajaran terkait mengembangkan keterampilan hidup dan hidup beragama di TK Khalifah anakanak dibekal melalui kegiatan sentra life skil. Sentra life skill (life skill centre) dirancang untuk menstimulasi anak agar menjadi mandiri, seperti makan sendiri dengan sikap yang baik, memakai dan melepas pakaian serta sepatu sendiri, merapikan sendiri mainan setelah bermain dan sebagainya.

Melalui sentra ini anak juga diharapkan dapat terampil dalam berinteraksi dengan orang lain. Anak diharapkan dapat saling bekerjasama, tolong menolong, bertoleransi dan lain-lainnya. Selain itu juga memberikan pengalaman kepada anak didik dengan berbagai macam peran yang ada di lingkunganya, bermain peran ini terbagi dalam dua kategori. Bermain peran makro dan mikro. Bermain peran makro seperti menjadi pedagang/pengusaha, dokter, guru, ayah, ibu, anak dan lain sebagainya sesuai dengan tema, 
Jurnal PG-PAUD Trunojoyo : Jurnal Pendidikan dan Pembelajaran Anak Usia Dini, Volume 8, Nomor 1, April 2021 hal 15 - 25, ISSN : 2528-3553 (online), ISSN: 2407-4454 (print)

sedangkan yang dimaksud dengan bermain peran mikro yaitu perannya menggunakan media pengganti bisa memainkan boneka, gambar seperti profesi petani, guru, polisi dan lain sebagainya.

Pemilihan media merupakan salah satu hal yang turut menentukan keberhasilan proses pembelajaran adalah pemilihan media pembelajaran yang tepat. Media pembelajaran yang tepat dapat memotivasi anak untuk belajar sehingga dapat memudahkan pemahaman dalam diri anak, selain itu anak juga merasa senang dan menikmati setiap proses pembelajaran.

Jika dilihat dari fasilitas sekolah dengan model pembelajaran sentra, untuk TK Khalifah Banjarmasin, pada dasarnya dalam ketersediaan media sudah cukup lengkap, dalam pemanfaatan media pembelajarannya pun sudah cukup baik. Media yang digunakan ada yang berupa media langsung atau melalui media-media gambar, APE (Alat Permainan Edukatif), papan tulis dan sebagainya. namun menurut pengakuan guru media yang digunakan dalam kegiatan enterprenuership harus banyak karena usaha tidak harus satu dan ini memungkinkan kurangnya media yang digunakan dan jika banyak pun pasti nanti akan rusak tidak selamanya bertahan.

Prinsip pembelajaran PAUD selanjutnya yaitu berorientasi kepada prinsip belajar anak. Proses pelaksanaan pembelajaran merupakan implementasi dari RPP yang sudah ditentukan, mulai dari kegiatan awal, pembukaan, inti dan kegiatan penutup. Di TK Khalifah Banjarmasin pelaksanaan pembelajaran mengacu pada RPP yang telah ditentukan sebelumnya dan dikembangkan sesuai dengan situasi dan kondisi pembelajaran yang sedang berlangsung.

Pelaksanaan kegiatan pembelajaran tersebut sesuai dengan yang diarahkan oleh Permendikbud bahwa kegiatan pembelajaran haruslah dilaksanakan berdasarkan tahapan kegiatan pembukaan, inti dan penutup (Permendikbud, 2015).

Dalam pelaksanaan kegiatan enterprenuership, guru mengungkapkan bahwa untuk penanaman enterpreneurship values atau soft skill pada anak, biasanya dilaksanakan dengan terlebih dahulu memberikan pemahaman terkait maksud dan makna dari karakter yang ingin dikenalkan. Misalnya, guru ingin menanamkan sifat jujur, maka guru akan menjelaskan dan memberikan contoh sifat jujur tersebut kepada anak. Ini bisa dilakukan dengan metode tanya jawab dan bisa juga melalui lagu. Selain itu, guru juga menggunakan metode bercerita agar anak semakin memahami dan meresapi makna dari sifat enterprenuership yang dikenalkan tersebut. Sedangkan untuk mengetahui apakah anak sudah mengamalkannya, guru biasanya menggunakan metode pemberian tugas, pembiasaan dan bermain peran.

Melihat hal tersebut, maka TK Khalifah mengenalkan enterpreneurship values kepada anak dengan mengadaptasi cara penanaman karakter yang dipaparkan oleh Licona yakni moral knowing, moral feeling dan moral acting (Sawa Suryana dan Lita Latiana, 2013: 46). Enterpreneurship values tersebut, ditanamkan oleh guru sejak anak datang ke sekolah sampai mereka pulang secara terintegrasi dengan berbagai kegiatan di Sekolah, tidak 
Jurnal PG-PAUD Trunojoyo : Jurnal Pendidikan dan Pembelajaran Anak Usia Dini, Volume 8, Nomor 1, April 2021 hal 15 - 25, ISSN : 2528-3553 (online), ISSN: 2407-4454 (print)

hanya pada kegiatan tertentu atau pada sentra tertentu. Namun demikian guru mengungkapkan bahwa sebagian besar enterpreneurship values dikembangkan pada anak saat mereka berada di sentra life skill. Begitu pula dengan penanaman hard skill kepada anak berupa literasi keuangan, membuat produk dan memasarkan produk, sebagian besar dikembangkan pada anak saat mereka berada di sentra life skill. Namun untuk memaksimalkan tersebut, TK Khalifah juga memiliki kegiatan tambahan lain seperti cooking day, berkaryawisata ke tempat pengolahan dan penjualan produk tertentu, market day dan ramadhan market. Kegiatan ini biasanya sudah terjadwal pada setiap puncak tema.

c. Evaluasi

Proses evaluasi tidak dapat terlepas dari proses penilaian dan pengukuran. Evaluasi sendiri bertujuan unntuk memantau kemajuan, hasil belajar dan perbaikan hasil belajar guna menjadi dasar untuk memotivasi dan membina perkembangan anak. Untuk mengevaluasi kegiatan interprenuership di TK Khalifah Banjarmasin, dewan guru menggunakan alat penilaian yang bervariasi, sesuai dengan kegiatan dan aspek-aspek perkembangan yang akan dinilai. Alat-alat penilaian yang digunakan di TK Khalifah Banjarmasin adalah lembar observasi, percakapan, produk, unjuk kerja dan catatan anekdot.

Alat-alat penilaian tersebut sudah dirancang oleh guru dan pihak-pihak sekolah. Sehingga kegiatan penilaian ini dapat dilakukan oleh guru atau guru pendamping sejak anak datang ke sekolah hingga jam pulang tiba.
Hasil penilaian langsung direkap setiap harinya di sekolah, sesaat setelah anak pulang sekolah. Hasil dari evaluasi inipun kemudian dilaporkan kepada orang tua secara rutin pada waktu yang telah ditentukan. Dengan demikian, dapat dikatakan bahwa TK Khalifah Banjarmsin memiliki prisip evaluasi perkembangan anak yang sistematis, berkesinambungan, transparan dan menyeluruh.

Pada lembar observasi, guru menggunakan ungkapan belum berkembang (BB), mulai berkembang (MB), berkembang sesuai harapan (BSH), dan berkembang sangat baik (BSB) sebagai kriteria dalam mengukur perkembangan anak. Kemudian setiap kriteria disertai dengan keterangan indikator yang menjelaskan maksud capaian perkembangan anak. Sehingga dapat dikatakan bahwa alat penilaian sudah bersifat objektif dan akuntable karena memiliki kriteria yang jelas dan dapat dipertanggung jawabkan. Memperhatikan hal tersebut, maka dapat disimpulka bahwa proses evaluasi perkembangan anak di TK Khalifah Banjarmasin telah berpatokan pada prinsip penilaian yang disampaikan oleh Peraturan Permendikbud (2015) yang mejelaskan bahwa prinsip penilaian di TK haruslah mendidik, berkesinambungan, objektif, akuntabel, transparan, sistematis, menyeluruh dan bermakna.

\section{Faktor Pendukung dan Penghambat Implementasi Kidspreneurship di TK Khalifah}

Pelaksanaan program enterprenurship di TK Khalifah tentunya tidak pernah terlepas dari faktor yang mendukung maupun yang menghambat terlaksananya. Faktor Pendukung pelaksanaan program kidspreneuship di 
Jurnal PG-PAUD Trunojoyo : Jurnal Pendidikan dan Pembelajaran Anak Usia Dini, Volume 8, Nomor 1, April 2021 hal 15 - 25, ISSN : 2528-3553 (online), ISSN: 2407-4454 (print)

TK Khalifah adalah; a) Koordinasi antara guru dan Orang tua, faktor ini merupakan hal pendukung dalam pembelajaran enterpreneurship karena orang tua dan guru harus selalu melakukan kerja sama sebelum melakukan kegiatan pembelajaran enterpreneurship semisal guru mau melakukan kegiatan outing ke peternakan sapi, tempat pembuatan sasirangan atau akan diadakan ramadhan market jadi guru dan orang tua terlebih dahulu berkomunikasi agar kegiatan tersebut berjalan sesuai yang diinginkan; b) Letak geografis, TK Khalifah terletak di daerah yang agak ramai dan bisa disebut daerah perdagangan sehingga sangat mendukung dalam kegiatan pembelajaran enterpreneurship, khususnya saat anak dan orang tua bekerjasama memasarkan atau menjual produk yang dibuat pada kegitan market day dan ramadan market; c) Teman sebaya, Teman Sebaya merupakan faktor pendukung dalam kegiatan enterpreneurship karena dalam melakukan setiap kegiatan diperlunya kerja sama antar anak. Contohnya saja anak diminta untuk bermain peran sebagai penjual dan pembeli maka tentunya setiap anak mempunyai peran masing-masing agar kegiatan ini dapat terlaksana.

Adapun faktor penghambat pelaksanaan program kidspreneuship di TK Khalifah adalah a) Kurangnya worhshop atau seminar tentang kidsprenuership, di Banjarmasin masih sangat minim dilaksanakan workshop dan semianr tentang pembelajaran enterpreneurship terutama untuk anakanak, baik itu tentang menumbuhkan enterpreneurship pada diri anak dll, walaupun terkadang pembelajaran enterpreneurship ada tetapi tidak untuk anak-anak. Sehingga TK memiliki keterbatasan pengetahuan untuk mengembangkan dan membuat inovasi kegiatan enterpeneurship untuk anak, b) Ukuran kelas dan sekolah, Kalau untuk ukuran kelas dan sekolah mungkin tidak ada kata cukup ibaratnya supermarket yang besarpun tetap saja menjadi kecil jika dipenuhi orang banyak tetapi itu tidak mengurangi kegiatan pembelajaran entrepreneurship, c) Media pembelajaran, dalam pembelajaran enterpreneurship media yang digunakan pasti harus banyak karena usaha tidak harus satu dan ini memungkinkan kurangnya media yang digunakan dan jika banyak pun pasti nanti akan rusak tidak selamanya bertahan, d) Koordinasi antara guru dan Orang tua, hal ini tidak hanya menjadi pendukung tetapi bisa juga menjadi penghambat karena terkadang ada orang tua yang tidak mau anaknya melakukan kegiatan seperti outing ke tempat-tempat terntu karena di rasa jauh dan membuat orang tua khawatir dengan anak.

\section{SIMPULAN}

Hasil penelitian menunjukkan bahwa program kidsprenuership di Tk Khalifah terbagi menjadi 2 program yang menitikberatkan pada soft skill dan hard skill. Soft skill yang dikembangkan kepada anak merupakan enterpreuership value. Sedangkan hard skill lebih kepada pengenalan bisnis kepada anak dalam bentuk literasi keuangan, membuat produk hingga memasarkan produk.

Soft skill dan hard skill ini diimplementasikan melalui knowing, feeling dan acting. Knowing dilaksanakan untuk mengenalkan anak terhadap konsep, ini diajarkan dengan metode bercakapcakap dan lagu. Feeling dilakukan dengan cara membacakan sebuah cerita. Sedangkan acting dilakukan melalui kegiatan bermain peran, metode pemberian tugas dan pembiasaan. Untuk memaksimalkan kegiatan kidpreneurship, TK Khalifah memiliki kegiatan tambahan lain seperti cooking day, berkaryawisata ke tempat 
Jurnal PG-PAUD Trunojoyo : Jurnal Pendidikan dan Pembelajaran Anak Usia Dini, Volume 8, Nomor 1, April 2021 hal 15 - 25, ISSN : 2528-3553 (online), ISSN: 2407-4454 (print)

pengolahan dan penjualan produk tertentu, market day dan ramadhan market.

Penerapan program kidspreneurship tidak terlepas dari berbagai faktor pendukung dan penghambat yaitu kerjasama antara guru dan orang tua, seminar dan workshop tentang kidsprenuership, media pembelajaran, letak geografis, ukuran kelas dan sekolah, dan teman sebaya.

\section{SARAN}

Dari kesimpulan yang telah didpaparkan, peneliti merekomendasikan saran-saran sebagai berikut:

1. Pendidik di TK Khalifah, dalam melaksanakan pembelajaran hendaknya disertai dengan tertibnya administrasi agar semua data perkembangan anak seperti hasil karya, penilaian perkembangan, maupun data diri terdokumentasikan dengan baik. Selain itu, meskipun seperangkat kurikulum sudah disipakan oleh pusat, akan lebih baik jika penyesuaian-penyesuaian yang dilakukan oleh TK Khalifah Banjarmasin juga teradministrasi dengan rapi dan baik.

2. Kepala Sekolah TK Khalifah, hendaknya diadakan pengadaan sarana pendidikan yang masih dibutuhkan, seperti ketersedian media pembelajaran, perpustakaan sekolah dan sarana-sarana lainnya yang berkaitan dengan penunjang program kidpreneurship di TK Khalifah.

3. Peneliti selanjutnya, diharapkan dapat melakukan penelitian yang berkaitan dengan program kidpreneurship di TK Khalifah dengan subjek yang berbeda dan mampu menggali data lebih mendala.

\section{DAFTAR PUSTAKA}

B, Suryoboroto. (2002). Proses Belajar Mengajar di Sekolah. Jakarta: PT.Rineka Cipta

Fadlillah, Muhammad \& Lilif Mualifatul Khoirida (2013). Pendidikan Karakter Anak Usia Dini: Konsep dan Aplikasiya dalam PAUD. Jogjakarta: Ar-Ruzz Media

Gibb, A. A. (1993). Enterprise Culture and Education Understanding Enterprise Education and Its Links with Small Business, Entrepreneurship and Wider Educational Goals. International Small Business Journal, 11(3), 11-34. http://dx.doi.org/10.1177/026624269 301100301

https://onlinemba.wsu.edu/teachingchildren-entrepreneurial-skills/

Jones, B., \& Iredale, N. (2010). Enterprise education as pedagogy. Education + Training, 52(1), 7-19. http://dx.doi.org/10.1108/004009110 11017654

Knight, F. H. (1921). Risk, uncertainty and profit. New York: Harper \& Row.

Komulainen, K., Naskali, P., Korhonen, M., \& Keskitalo-Foley S. (2011). Internal entrepreneurship -A Trojan horse of the neoliberal governance of education? Finnish pre-and in-service teachers' implementation of and resistance towards entrepreneurship education. Journal for Critical Education Policy Studies, 9(1), 341374.

Korhonen, M., Komulainen, K., \& Räty, H. (2012). Not everyone is cut out to be the entrepreneur type: How Finnish school teachers construct the meaning of entrepreneurship education and the related abilities of the pupils. Scandinavian Journal of Educational Research, 56(1), 1-19. http://dx.doi.org/10.1080/00313831. 2011.567393

Lerner, M., \& Almor, T. (2002). Relationships among strategic capabilities and the performance of women-owned small ventures. Journal of Small Business Management, 40(2), 109-125. http://dx.doi.org/10.1111/1540627X.00044

Lindström, L. (2013). What Do Children Learn at Swedish Preschools? 
Jurnal PG-PAUD Trunojoyo : Jurnal Pendidikan dan Pembelajaran Anak Usia Dini, Volume 8, Nomor 1, April 2021 hal 15 - 25, ISSN : 2528-3553 (online), ISSN: 2407-4454 (print)

International Education Studies, 6(4), 236.

http://dx.doi.org/10.5539/ies.v6n4p2 36

Masitoh, dkk. (2009). Strategi Pembelajaran TK. Jakarta: Universitas Terbuka

Mulyani, Endang. dkk. (2010), Pengembangan Pendidikan

Kewirausahaan. Jakarta: Kementrian Pendidikan Nasional

Ms, Indrawan. (2000). Kamus Lengkap Bahasa Indonesia. Jombang: Lintaas Media.

Ningrum, Anik Lestari (2017) Perencanaan Pembelajaran Anak Usia Dini. Nganjuk: Adjie Media Nusantara

Peraturan Menteri Pendidikan dan Kebudayaan Republik Indonesia Nomor 146 Tahun 2015.

Peraturan Menteri Pendidikan Nasional Republik Indonesia Nomor 58 Tahun 2009

Peterman, N. E., \& Kennedy, J. (2003). Enterprise education: Influencing students' perceptions of entrepreneurship. Entrepreneurship Theory and Practice, 28(2), 129-144. http://dx.doi.org/10.1046/j.15406520.2003.00035

Robinson, K. (2006). Do schools kill creativity? Paper presented at the TED2006 conference. Monterey, CA

Rosyana, Dhian Farah (2014) Pembelajaran Nilai-Nilai Kewirausahaan Bagi Anak Usia Dini. Skripsi, Universitas Negeri Yogyakarta http://digilib.uinsuka.ac.id/33586/1/14430013

Santika, Tika, (2017). Pendidikan Karakter Kewirausahaan Pada Program Pendidikan Anak Usia Dini (PAUD). Jurnal Pendidikan NonFormal.
Fakultas Ilmu Pendidikan Universitas Bengkulu, Vol. 1 No. 1

Schumpeter, J. A. (1934). The Theory of Economic Development. Cambridge, MA: Harvard University Press.

Seikkula-Leino, J. (2011). The implementation of entrepreneurship education through curriculum reform in Finnish comprehensive schools. Journal of Curriculum Studies, 43(1), 69-85.

http://dx.doi.org/10.1080/002202709 03544685

Suryana, Sawa \& Lita Latiana, (2013) Character Education Model in Early Age Childhood. International Journal of Early Childhood Education Studies, 2 (1) 2013 ISSN 2252-6374

Soemanto, Wasty (2008). Kewiausahaan untuk Mahasiswa dan Umum. Bandung: Alfabeta

Surlemont, B. (2007). Promoting enterprising: a strategic move to get schools' cooperation in the promotion of entrepreneurship. In A. Fayolle (Ed.). Handbook of Research in Entrepreneurship Education: Contextual perspectives. Cheltenham, UK: Edward Elgar.

Syifauzakia. (2016). Penanaman NilaiNilai Kewirausahaan Pada Anak Usia Dini Melalui Metode Proyek. Jurnal Tunas Siliwangi, vol.2, No.1. http://ejournal.stkipsiliwangi.ac.id/in dex.php/tunassiliwangi/article/downl $\operatorname{oad} / 311 / 232$

Timmons, J. A., Muzyka, D. F., Stevenson, H. H, \& Bygrave, W. D. (1987). Opportunity recognition: the core of entrepreneurship. Frontiers of entrepreneurship research, 109-123. 